\title{
POLYCENTRICITY AND COMMUTING. AN APPLICATION TO METROPOLITAN AREAS IN THE SOUTH OF POLAND
}

DOI: https://doi.org/10.18509/AGB.2018.09

UDC: $656.131(438)$

\author{
Elżbieta Zuzańska-Żyśko \\ University of Silesia, Faculty of Earth Sciences, Department of Economic Geography, Poland \\ Corresponding author: elzbieta.zuzanska-zysko@us.edu.pl
}

Submitted: 20.02.2018, Accepted: 15.04.2018, Published: 30.09.2018

\begin{abstract}
Commuting is an element of functional interrelations in metropolitan regions. They determine the nodes of a settlement system and portray economic attractions. The purpose of the article is to designate the dominant directions of commuting in a polycentric and post-industrial region - the Górnośląska-Zagłębiowska Metropolis in the south of Poland. The article analyses the influence of urban structures on commuting in the period of 2006 and 2011. The Nystuen-Decey method has been employed in order to grasp the spatial patterns of work places in the metropolitan area. The results of examinations prove that communing is very complex and creates the system of social-economic interrelations with the main centre of Katowice.
\end{abstract}

Keywords: Commuters flows, polycentricity, post-industrial region, metropolitan area

\section{INTRDUCTION}

The processes of globalization and metropolization influence the high level of intensity and spatial mobility in terms of the of labour market in metropolitan areas. The biggest global cities represent extraordinarily large labour markets and diversified types of global economies.

The problem of commuting is a subject of numerous elaborations. On one hand, directions and the size and intensity thereof present nodes of labour markets, on the other hand the background and zone of interactions of centres. Moreover, they indicate the structure of flows and power of interactions in the regions, simultaneously characterizing the type of settlement system from a monocentric one to a non-hierarchical one - polycentric. The size of metropolitan centre, as well as its strength, influence the length of commuting, whereas the development of infrastructure strengthens or limits flows, affecting at the same time the power of interrelations from different directions. They can be weak, average or strong [15], symmetric or asymmetric [23].
In Europe there is a highly diversified level of commuting in various metropolises, depending on the hierarchy thereof in the worldwide system of global cities $[9,1]$. Commuting on highest level in Europe occurs in London (Inner London-West). They can be characterized by long distances, which results from the strength of this metropolis, as well as a well developed public transport system [29]. Paris is of a similar situation. This highly monocentric functional urban area attracts employees from smaller Functional Urban Regions, also closely located, such as: Mantesla-Jolie, Meaux, Melun, Creteil, Chartres, just as bigger surrounding peripheral centres forming a subregional network of centres [12]. Similarly, other monocentric agglomerations in Europe, e.g., Hamburg and Berlin in Germany, Brussels in Belgium, Vienna in Austria ) Moscow in Russia or Prague in Czech Republic are characterized by intensified commuting [2,6, 7, 11,14, 26, 29].

Of a slightly different character are polycentric structures where commuting is very complex, shorter yet very intense [9]. In Randstad in the 
Netherlands, most of commuting is of a shortdistance type. It results from a different genesis of the metropolitan area - a form of port conurbation. The polycentricity of cores is a characteristic feature thereof. Therefore, commuting is dispersed among several cities: in the region of Amsterdam, as well as between Rotterdam and Hague [23]. A similar situation occurred in Rheine-Ruhr in Germany where, in turn, the polycentric functional-spatial structure is of an industrial genesis [11]. Currently, this economic sector is completely restructured, whereas the region is based on modern technologies. In terms of commuting, of a dominant character is Düsseldorf, as well as the cores of Bonn and Cologne. Simultaneously, there are strong flows between the cities of Ruhrgebit, such as Essen, Bochum and Dortmund. On the other hand, in a different German metropolitan area - the region of Rheine-Main, flows of commuters are dominated by FUR of Frankfurt, the quantity of employees of which exceed 1 million. Approximately 200 thousand of them commute from the background, whereas 72 thousand from other functional urban regions [10].

Commuting in Europe has been introduced to nearly all metropolises. The analysis of daily mobility allows to broaden the knowledge on the characteristics thereof, as a factor of the functioning of settlement system. In case of Daily Urban Systems which form metropolitan regions, commuting reveals functional interrelations, as well as indicates essential structural features. Of utmost importance is the indication of poles of growth of these interrelations. The process of metropolization is obviously connected with a strong flow of commuters towards the core. All the more the functional-spatial relations between a metropolitan area and the surrounding background are principal. As is often observed, the factual interrelations of cities is greater than their appointed administrative boundaries or NUTS3 statistical units, i.e. Subregions $[3,36]$.

\section{METHODOLOGY AND STUDY AREA}

The purpose of the article is the determination of the dominant direction of commuting in the post-industrial region of southern Poland which - due to a transformation - changes from a polycentric conurbation to a metropolitan area. The subject of studies is in Silesia. By act, this conurbation-type settlement system became the first lawful and legal metropolitan structure in 2017 , by the name of Górnośląsko-Zagłębiowska Metropolis. It is inhabited by 2.47 million people and encompasses 41 municipalities. The core is composed of 13 cities with county rights (NUTS4). It is surrounded by a metropolitan area composed of 28 municipalities (NUTS5), as well as different cities (medium, small) and rural municipalities.

Source materials originate from Main Statistical Office (GUS). The flows of employment in Poland in 2006 and 2011 were analysed on the basis of the POLTAX tax system, with the usage of data on workers with employment contracts. The community of commuters encompassed hired workers inhabiting a municipality different than their workplace, with higher costs of revenue due to commuting [4]. The study was updated in 2011 with the usage of NSP data (excluding individual farmers).

The data on commuting were analysed for the core of the Górnośląsko-Zagłębiowska Metropolis, composed of 13 cities with county rights, as well as the vicinity thereof. In order to appoint the dominant directions of commuting, the method of Nysteun and Dacey [18] was used. It determines the system of relations of the basis of the highest flow criterion. It portrays a simplified system or relations in a settlement system, as well as arranges the high complexity of system relations.

On the basis of commuting matrix between the centres in the core of GórnośląskoZagłębiowska Metropolis, as well as the highest outflow and inflow to a different core city, the main nodes of interrelations were determined. Also the dominant direction of flows of the labour market were specified.

\section{COMMUTING IN POLAND}

In 2006, the group of taxpayers exceeded 9.5 million, out of which the community of commuters accounted for 2.3 million, approximately $1 / 4$ of the entire labour market. 
In turn, in 2011 there were 3.1 million commuters $[4,5]$. On the basis of interregional flows, it may be concluded that the most attractive labour market was Mazovia. In relation to the fact mentioned above, the highest number of commuters was recorded in Warsaw which has the most favourable ratio of flows: 13.07 and 10.7 (2006 and 2011). It indicates that one leaver was represented by as many as 13 and 10 comers. The highest flows in terms of absolute values were recorded in Silesia, nearly 400 thousand people in 2006 and 487 thousand in 2011. It may be attributed to a strong labour market, as well as the urbanization level which reaches $78 \%$ of urban inhabitants in the region, with a nationwide average of $61 \%$. The proportion of commuters in Silesia is so much as $16.8 \%$ of national flows in 2006 and $15.6 \%$ in 2011. A particularly high intensity was recorded for some province capitals and, at the same time, metropolitan centres gathering 680 thousand hired workers: $25 \%$ of commuting to the capital of Poland - Warsaw, $15 \%$ to Katowice, 9\% to Kraków and Poznań, 6\% to Wrocław, $5 \%$ to Łódź and $4 \%$ to Gdańsk.

The balance of comers to leavers was positive in Silesia to reach in $2006+5.6$ thousand, nevertheless in 2011 decreased to +0.8 thousand. On the basis of the fact mentioned above, it may be concluded that the attractiveness of the region as a labour market decreases, despite the fact that commuting accounted for 53 thousand. Only in four regions of Poland the number of comers was higher than leavers. Apart from Silesia, they were: Mazovia, Lower Silesia and Greater Poland [5].

Warsaw and the region of Maziovia, as well as Katowice with the new structure of Górnośląsko-Zagłębiowska Metropolis, are the areas of most dynamic commuting. Two metropolitan areas shall be pointed out to: Lower Poland and Upper Silesia. Due to a favourable transport location and a relatively small distance $(80 \mathrm{~km})$ between the capitals of these two regions - Kraków and Katowice, an significant interrelations of labour markets is visible. There are strong directions of interactions and diffusions here, as well as a very intense intraregional and interregional circular migrations. Employees of 63 municipalities commute from Lower Poland
(20\% of commuting). Also in the opposite direction commuting occurs. In European projects this area is considered as one metropolitan region, describes as KrakówUpper Silesia Cluster (PolyMetrex). The contact region [27] of these two regions is a place of a high dispersion of the gravity of cities. They exceed the administrative boundaries of regions. Stronger contact interrelations of towns and cities in the boundary of these regions may be observed. The issue of commuting in Poland is included in many studies carried [13, 24, 25, 30, 31, 32, 34].

\section{RESULTS \\ GÓRNOŚLĄSKO-ZAGLEBIOWSKA METROPOLIS: EMPLOYMENT COMMUTING AND POLYCENTRICITY}

Each labour market exists in a predefined space and has its boundaries of interactions. Commuting in Górnośląsko-Zagłębiowska Metropolis can be characterised with high intensity and complexity, not only in the region, but in the nationwide scale as well. 239 thousand employees commuted to the polycentric core in 2011. 93\% of it was intraregional commuting, whereas $7 \%$ interregional ones (Fig. 1). They constitute a reflection of the potential of labour market and economic development for the polycentric area with a clearly forming centre of the metropolitan area - Katowice. The flows are multidirectional, i.e. employees travel between 13 cities of the core, forming a network of relations (123 thousand, 53\% of total commuting to the core; Fig. 1).

The external zone has the total of 48 thousand of commuters, that is $19 \%$ of all employees commute to the core from the direct metropolitan area. 22\% (53 thousand) employees commuted from the remaining municipalities of the Province to 13 core cities. Intracore commuting and the commuting from the direct ring accounted for 171.3 thousand commuters. It translates into $71 \%$ of all commuting to the core.

Taking into consideration the Nystuen-Deceya method [18], on the basis of the highest flow, the high rank of Katowice, as the capital of the Górnośląsko-Zagłębiowska Metropolis, clearly distinguishes itself (Fig. 2). An observation arises that the spatial arrangement 
of migration behaves differently (atypically) in relation to other areas in Poland [21]. J. Runge [25] highlights this fact. It is related to the polycentric functional-spatial structure of this area, as well as the genesis of settlement form originating from the polycentric system in the form of a conurbation [16]. Such urban systems are characterized by the polycentricity and blurring (fuzziness) of central functions [35]. The economic activeness and labour market disperse in a broad area - in many cities of different standings and size [28]. The method applied portrays a simplified system or relations in a settlement system, as well as arranges the high complexity of system relations. In Poland, the farther from a province city the smaller the intensity of flows and commuting. In the area under analysis it is not unequivocal. The areas of commuting to work and labour market structures in the region overlap. They shaped as early as during the industry development period, namely in the seventies and eighties of the twentieth century [24], whereas in the last 20 years they have undergone a transformation. The current socio-economic situation is a result of profound and painful restructuring [22], modernization and the development of motorization, new road investments, increased availability of the region in European transport corridors.

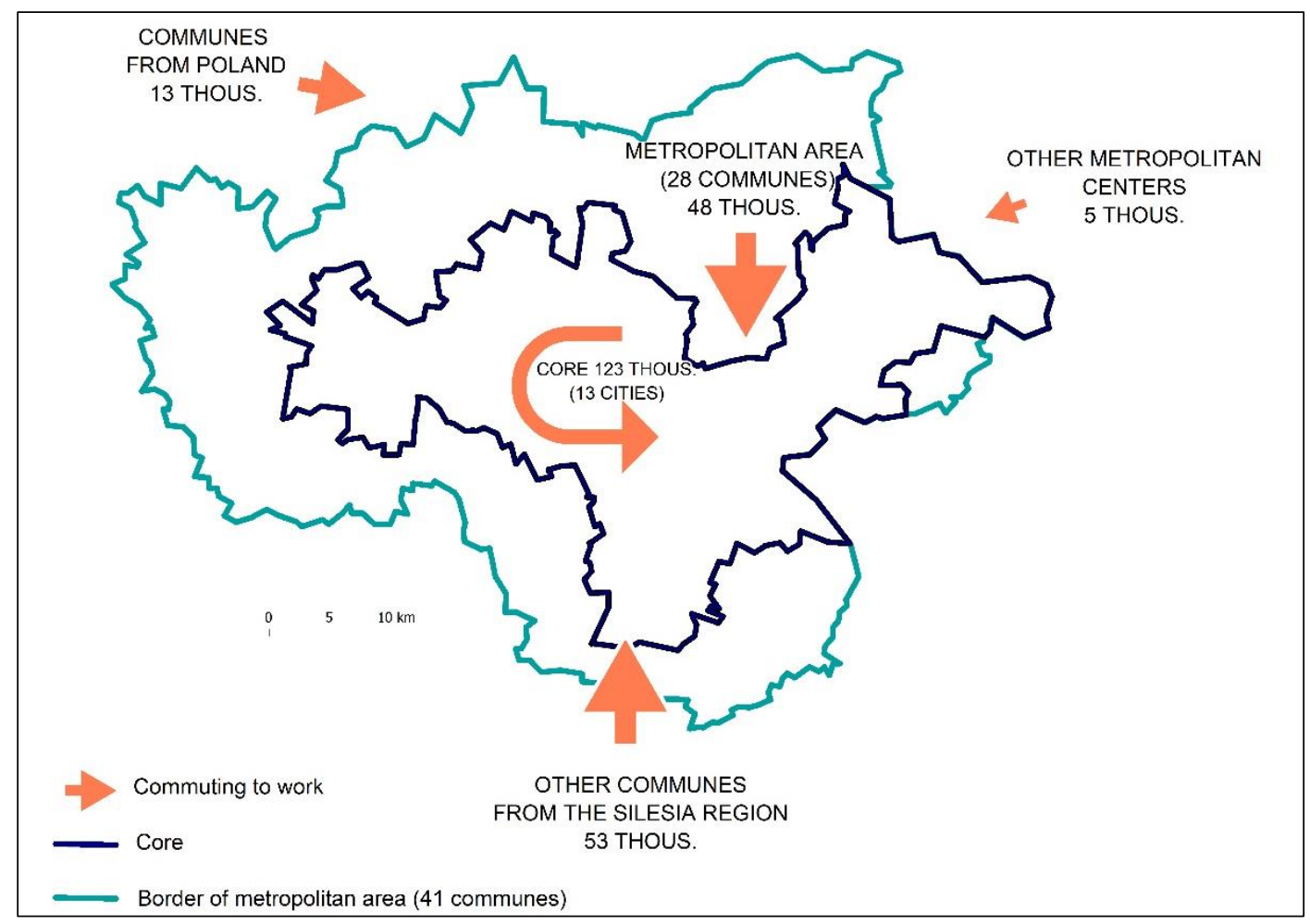

Figure 1. Commuting to the core of Górnośląsko-Zagłębiowska Metropolis in 2011 source: author's elaboration

In the light of the region under investigation, Katowice is a city most attractive in terms of labour resources. Katowice plays the role of a main centre in commuting in GZM, gathering the total of 122 thousand commuters. Katowice is the runner up in Warsaw in terms of the amount of commuters. In 2006, Katowice attracted $15 \%$ of all commuters in the country, which translates into a positive circular migration balance. One leaver is represented by 9 comers from other cities and villages (2006) and 7 of them in 2011. The distance the commuters have to cover to reach Katowice is significant. The city is a commuting centre for 98 municipalities (over $10 \%$ ). The dominance of Katowice, as the centre of gravity, is clearly visible. It is the main pole of development and the centre of the GZM core. An increase in commuting amounted to 18 thousand in 5 years. It gives evidence of significant interrelations, not only of a regional character, but interregional ones 
as well, and a principal rank of Katowice in the economic system. These flows portray Katowice as a centre of a high potential of labour market, on the level of 275 thousand of employees [20, 28]. Nearly all other metropolitan sub-centres in GZM are under the influence thereof, draining them from workplaces. Simultaneously, it is a strong labour market of the most developed metropolitan functions in the region [35]. Complex and dynamic commuting may be a premise of the undergoing metropolization processes. Circular migrations (commuting) is one of the measures of mobility which prove the occurrence of socio-economic relations in the region [34]. Travelling to work is also one of the fundamental factors of the formation of a functional urban region. Studies done in Randstad in Holland, a similar polycentric settlement system as GZM, reveal a great diversity of commuting in terms of distances. Similar trends occur in Ruhrgebit.

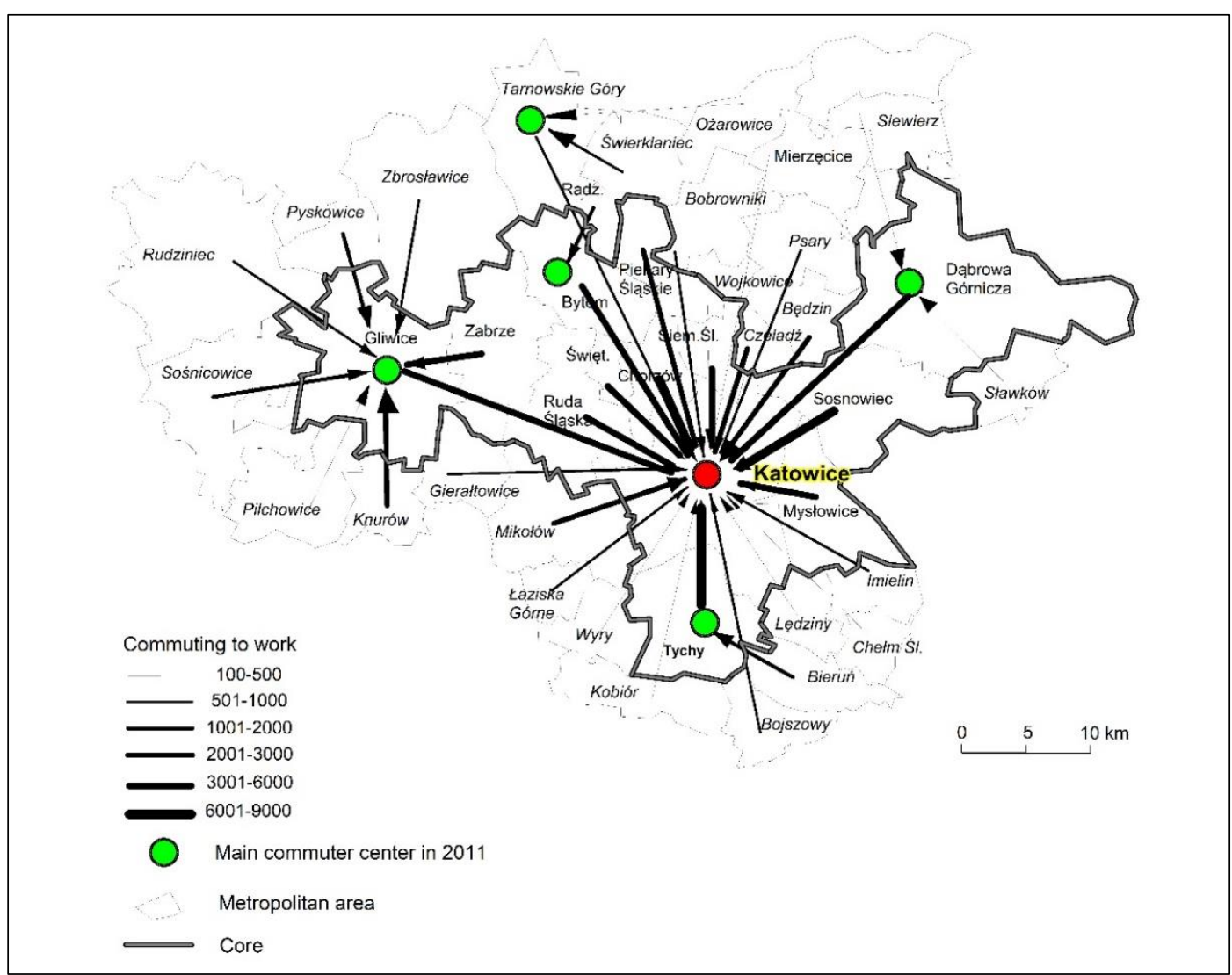

Figure 2. Main directions of commuting in Górnośląsko-Zagłębiowska Metropolis in 2011. source: author's elaboration

Due to the polycentricity of the settlement system, the power of other core cities is underestimated in the studied area. They also generate massive internal flows, shape transport, infrastructural and institutional interrelations. The similarity of the occurring processes - flows of labour markets - is, inter alia, the power of polycentricity and network systems. Gliwice is the second biggest node of functional relations in GZM (Fig. 2). The city forms a western subcentre of the metropolitan area. It is also confirmed by the research of $\mathrm{J}$. Petryszyn [19] or K. Gwosdz [8]. The city formed its own influence zone, whereas its domination is substantial, since in some municipalities in the area are responsible for as much as $71 \%$ of commuting. The area of influence of $30 \%$ and more commuting encompasses 7 municipalities (2006), however, taking into account commuting of less intensity (2011), the interrelations of Gliwice embrace 55 different municipalities. Analyzing the size commuting in the light of hierarchy in the studied area, Gliwice shifts toward Katowice (2.2 thousand commuters in 2006, 2.9 in 2011). Due to the dominant 
directions of commuting, Gliwice forms a separate daily urban system. In relation to the dominance of Gliwice and Katowice, according to the factor of commuting on the level of $30 \%$, two areas of influence are clearly visible. The boundary between those two cities lies in the western part of the core, in the area of Zabrze.

Also other relations within the core manifest themselves. Commuting to work is extremely high, on the level of 123 thousand. They are of a very complex nature and multidirectional. Nonetheless, only four cities have a ratio of flows exceeding 1. They are: Katowice, Gliwice, Tychy and Dąbrowa Górnicza. Nevertheless, similar flows of employees -7 to 11 thousand - occur in Chorzów, Sosnowiec, Dąbrowa Górnicza, Zabrze and Tychy. The global commuting thereof (also from other municipalities, e.g. from the province or outside of the external zone and other regions of Poland) is within the range of 10-16 thousand. In Tychy, a high proportion of commuting from the direct vicinity of the background is visible. This city formed its own area of influence, due to significant investments, particularly in industrial processing - automotive industry. From a satellite centre of Katowice in the seventies of the twentieth century [17], Tychy became a major labour market in the south of the core. In the remaining cities, commuting from the direct external area is less intense and reveals the domination of influence of other core cities [28]. These flows of commuting confirm the regularity that each urban centre, independently of itself being a central element of a local settlement system of a character similar to functional urban area, may regardless of the size and rank - be incorporated in other subsystems, the regional and metropolitan ones.

The scale of commuting to the core from other metropolitan centres in Poland is relatively small. It encompasses approximately 5 thousand commuters only. It suggests that the relations of labour market in a metropolitan scale are weak, despite the fact that Katowice reveal connections with all metropolitan centres in Poland. They are significantly stronger with Kraków (3.3 thousand) than with Warsaw (0.6 thousand). Out of other core cities of GZM, also Dąbrowa Górnicza has strong relations with Kraków. 2.3 thousand commuters arrive there. In turn, two other core cities, Świętochłowice and Piekary Śląskie, do not reveal any interrelations with other metropolitan centres. This confirms the fact of a low position of these cities in the economic system of the examined area, as well as a low rank in the structure of core cities.

In relation to the complexity of commuting and the functional structure, a more advanced daily urban system (vast functional urban area) stands out, as well as four functional urban areas which form Metropolitan Region Silesia [36].

Tarnowskie Góry plays a significant role in the north-western part. It is a significant county centre which developed its own area of influence. Despite the fact that Tarnowskie Góry are not located it the core area, the city developed its own high-order functions and a full auxiliary function to the benefit of the metropolitan area [35]. The abovementioned confirms the force of influence of Tarnowskie Góry, as a county centre and a significant subcentre, of a lower rank, that is located in the north-western part of the metropolitan area.

\section{CONCLUSIONS}

Commuting in GZM represents a very complex system of functional interelations. It refers to network interrelations which result from the dispersion of labour markets of the cities of the polycentric core. Despite the fact that commuting is multidirectional, the role of Katowice as the main flow node is clearly distinguishable. Katowice plays the dominant role not only in intra-core interrelations, but the whole metropolitan area as well. It results from a vast labour market, good transport availability, central location, as well as certain high-order functions, including the metropolitan ones. In the western part, the role of the sub-centre of Gliwice manifests itself strongly. It is an important labour market and a node of relations of a lower order. To a lesser extent, Dąbrowa Górnicza (north-east) and Tychy (south) also stand out. 


\section{REFERENCES}

[1] Aguilera A., Mignot D., Urban Sprawl, polycentrism and commuting. A comparison of Seven French Urban Areas, Urban Public Economics Review, 1, pp 93-113, 2004.

[2] Blotevogel H., Schulze K., 1 oder 2 oder 3? Zur Konstituierung möglicher Metropolregionen an Rhein und Ruhr, Raumforsch Raumordn, 68, pp 255-270, 2010.

[3] Boix R., Veneri P., Almenar V., Hernández F., Polycentric metropolitan areas in Europe: towards a unified proposal of delimitation, in: New Challenges for European Regions and Urban Areas in a Globalised World, 51 European Congress of the Regional Science Association International, Spanish Regional Science, Barcelona, pp 21-22, 2011.

[4] Dojazdy do pracy w Polsce. Terytorialna identyfikacja przepływów ludności związanych z zatrudnieniem, GUS-US, Poznań, 2010.

[5] Dojazdy do pracy. Narodowy Spis Powszechny Ludności i Mieszkań 2011, GUS, Warszawa, 2014.

[6] Dujardin S., Boussauw K., Brévers F., Lambotte J-M., Teller J., Witlox F., Sustainability and change in the institutionalized commute in Belgium: Exploring regional differences, Applied Geography, vol. 35, 1-2, pp 95-103, 2012.

[7] Ginko M., Nefedova T., Coping with employment issues through commuting: Evidence from Central Russia, Moravian Geographical Reports, 25 (2), pp 118-128, 2017.

[8] Gwosdz K., Pomiędzy starą i nową ścieżką rozwojową. Mechanizmy ewolucji struktury gospodarczej i przestrzennej regionu tradycyjnego przemysłu na przykładzie konurbacji katowickiej po 1989 roku, IGiGP UJ, Kraków, 2014.

[9] Hall P., Pain K., (eds.), The Polycentric Metropolis: Learning from Mega-City Regions in Europe, Earthscan, London, 2006.

[10] Hall P., Pain K., Green N., The Informational Geography of Europolis: Mapping the Folow of Information, [in:] P.Hall, K. Pain (eds.) Polycentric Metropolis. Lerarning from Mega-City Regions in Europe, Earthscan, London-Washington, pp 70-87, 2006.

[11] Jacobs M., Vanderbiesen W., Inter-Regional and Cross-border Mobility in the Flemish Labour Account, [in:] Measuring Geographical Mobility in Regional Labour Market Monitoring: State of the Art and Perspectives, (eds.) CH. Larsen, R.Hasberg, A.Schmid, M. Bittner, F. Clemént, Rainer Hampp Verlong, München, Mering, Germany, pp 177-188, 2011.

[12] James N., 2012: Déplacements domicile-travail: l'attraction francilienne sur les actifs des départements

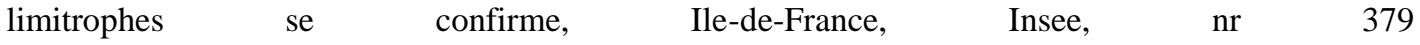
http://www.insee.fr/fr/themes/document.asp?ref_id=18200\#deux,

[13] Korcelli P., Potrykowska A., Bodzak D., Układ przestrzenny współzależności ośrodków dojazdów do pracy. Studia nad migracjami i przemianami systemu osadniczego w Polsce, Prace Geograficzne IGiPZ PAN, 140, Warszawa, pp 213-233, 1981.

[14] Kraft S., Halás M., Vanćura M.,Tthe delimitation of urban hinterlands. Based on transport flows: a case study of regional capitals in the Czech Republic, Moravian Geographical Reports, 22, 1, pp 2432, 2014.

[15] Limtanakool D., Narisra M , Schwanen T., Dijst M., Development in Hierarchy in the Dutch Urban System on the Basis of Flows, [in:] Sustainable transport: hot or not? Colloquium Vervoersplanologisch Speurwerk (CVS), Rotterdam, 2005.

[16] Liszewski S., Aglomeracja miejska. Geneza. Przemiany, [in:] I. Jażdżewska (red.), Współczesne formy osadnictwa miejskiego i ich przemiany, XV Konwersatorium Wiedzy o Mieście, Uniw. Łódzki, Łódź, pp 21-34, 2002.

[17] Litewka C., Miasta satelity. Zakres pojęć i kierunki budownictwa satelitarnego, Czasopismo Geograficzne, 1-2, pp 29-51, 1979.

[18] Nystuen J., Dacey M., A graph theory interpretation of nodal regions, Gographia Polonica, 15, pp 135$151,1968$.

[19] Petryszyn J., Główne centra Metropolii "Silesia", Acta Geographica Silesiana, 10, WNoZ UŚ, Sosnowiec, pp 36-44, 2011.

[20] Petryszyn J., Zuzańska-Żyśko E., Osadnictwo miejskie GZM, [w:] R. Dulias, A. Hibszer (red.), Górnośląski Związek Metropolitalny. Zarys geograficzny, PTG Oddział Katowicki, Sosnowiec, pp 180-189, 2008.

[21] Raźniak P., Winiarczyk-Raźniak R., Influence of the Societal Security Level on Population Migrations in Poland, Procedia - Social and Behavioral Sciences, Vol. 120, pp 2-12, 2014. 
[22] Riley R., Tkocz M., Coal mining In Upper Silesia under communism and capitalism, Europen Urban and Regional Studies, v. 5, 3, pp 217-235, 1998.

[23] Ritsema van Eck J., Snellen D., Is the Randstad a city network? Evidence from commuting patterns, Netherlands Institute for Spatial Research, Hague, 2006.

[24] Runge J., Dojazdy do pracy w przestrzennej strukturze powiązań miast województwa katowickiego, Wyd. UŚ, Katowice, 1991.

[25] Runge J., Rynek pracy województwa śląskiego, [in:] J.Runge, I.Żurek (eds.), Procesy i struktury demograficzno-społeczne na obszarze województwa śląskiego w latach 1988-2008, US w Katowicach, pp 111-165, 2010.

[26] Schmitt P., Volgmann K., Münter A., Reardon M., Unpacking polycentricity at the

city-regional scale: Insights from Dusseldorf and Stockholm, European Journal of Spatial Development, 59, pp 1-26, 2015.

[27] Sitek S., Stykowość obszaru i jej wpływ n przebieg procesów społeczno-ekonomicznych na przykładzie południowej części województwa śląskiego, Wyd. UŚ, Katowice, 2010.

[28] Sitek S., Zuzańska-Żyśko E., Small Towns in Metropolitan Silesia Region in the Context of Commuting to Work, [in:] A.Kwiatek-Soltys, H. Mainet, K.Widermann, J-C. Edouard (eds.), Small and Medium Towns' Attractiveness at the beginning of the 21st Century, CERAMAC (Centre for Research on Massif Central, Mountains and Fragiles Territories), France, pp 269-286, 2014.

[29] Statistics on commuting patterns at regional level, 2016; http://ec.europa.eu/eurostat/statisticsexplained/index.php/Statistics_on_commuting_patterns_at_regional_level\#Which_regions have the highest_shares_of outbound_commuters.3F

[30] Szajnowska-Wysocka A., Zachowania przestrzenne ludności konurbacji górnośląskiej. Synteza badawcza, Wyd. UŚ, Katowice, 1999.

[31] Szymańska D. (ed.), Procesy i formy ruchliwości przestrzennej ludności w okresie przemian ustrojowych, Wyd. UMK, Toruń, 2000.

[32] Śleszyński P., Delimitacja Miejskich Obszarów Funkcjonalnych stolic województw, Przegląd Geograficzny, 85, 2, pp 173-197, 2013.

[33] Venerii R., The identification of sub-centres in two Italian metropolitan areas: A functional approach, Cities, 31, pp 177-185, 2013.

[34] Zborowski A., Przemiany struktury społeczno-przestrzennej regionu miejskiego w okresie realnego socjalizmu i transformacji ustrojowej (na przykładzie Karkowa), IGiGP UJ, Kraków, 2005.

[35] Zuzańska-Żyśko E., Funkcje metropolitalne Górnośląskiego Obszaru Metropolitalnego, Studia Regionalne i Lokalne, nr 2, 48, pp 39-61, 2012.

[36] Zuzańska-Żyśko E., Region Metropolitalny Silesia w świetle koncepcji funkcjonalnych, [w:] T. Kudłacz, P. Brańka (red.), Teoria i praktyka rozwoju obszarów funkcjonalnych, Studia KPZKPAN, T. CLXXIV, pp 116-125, 2017. 